\title{
The Effectiveness of Future Problem-Solving Program (FPSP) in Developing Creative Thinking Skills Among Gifted Students: Experimental Study
}

\author{
Abd-Alrhman Alzahrani \\ Al-Baha University, Saudi Arabia \\ Dr. Yahya Al-Dhaimat \\ Department of Special Education, Al-Hussein Bin Talal University, Ma'an, Jordan \\ Dr. Awni Shahin \\ Department of Special Education, Mu'tah University, Karak, Jordan
}

\begin{abstract}
The study aimed at developing an enrichment program based on Future Problem Solving Program (FPSP), and revealing its impact on the development of creative thinking skills among $1^{\text {st }}$ secondary grade gifted students in Al-Baha region. The experimental approach was used and a sample consisted of (24) students was selected. They were divided randomly into two groups: the experimental sample (14 students) and the control sample (10 students). The researchers developed the current study program based on the future problem-solving program (FPSP) and a creative thinking skills scale. The tool validity and reliability were extracted and checked. Results showed significant differences in the performance between the two groups (experimental and control) on the post-test in favor of the experimental group. There were also significant differences between the performance of the experimental group in the pre- posttest, in favor of the post-test on the scale and its different dimensions. This indicates the effectiveness of the enrichment program presented in the current study and its advantage in developing the creative thinking skills for gifted students in regular classroom. In addition, there was a significant difference between the performance of the experimental group in the post- follow-up test, in favor of the followup performance on the scale as a whole and its different dimensions.
\end{abstract}

Keywords: effective studies, future Problem-Solving Program (FPSP), special gifted class, creative thinking.

DOI: $10.7176 / \mathrm{JEP} / 11-9-16$

Publication date:March $31^{\text {st }} 2020$

\section{Introduction}

1.1 Enrichment Programs

The gifted students are the future leaders and the main pillar upon which the humanity future depends on to accomplish the scientific achievements as well as the advanced technology. Therefore, all the societies, since the early times up to now, have paid a considerable attention to promoting them and developing their capabilities due to their importance in a manner manifested by achieving tangible scientific achievements. This, in turn, develops the potentials of their countries and increases their levels of luxury. This enhancement develop their creative thinking and design new programs that match with the current changes which would help them in solving the problems that face them in diverse and creative ways.

The Kingdom of Saudi Arabia has witnessed a rapid development and advances in many fields, namely, economics, politics, cultural and technical advancement which, in turn led to a gradual development in gifted care. To discover their talents and take better care of them, the Ministry of Education and other national institutions have worked on issuing new legislations for gifted and conducting researches and projects to amending the national educational policy. In addition, departments and centers (talent (Mawhiba), the institution of King Abdul-Aziz and his companions) were established to provide gifted with appropriate services, such as preparing enrichment programs to develop their capabilities in separated classrooms and re-codifying scales measuring their talents including the scales of creative thinking. The specialized centers help them obtain a diverse and distinguished education that challenges their abilities and satisfies their needs in accordance with best teaching methods. Some other ways to develop their talents are: making competitions and providing rewards, training the teachers and staff working with gifted students, and raising the awareness of local society and families to participate in taking care of gifted students about the importance services as well as making efforts to establishing special classrooms for them in the public schools (the guide of talented classrooms, 2015, pp.4). Nevertheless, the desired outcomes aren't still insufficient due to the modernity of the program and the nature of care provided to the gifted students in the Kingdom of Saudi Arabia.

Employing enrichment programs is considered as one of the most common programs in the world because it is cost-effective and acceptable. Enrichment programs for gifted students have some other advantages such as 
allowing them to pursue their study, having more and deep understanding of the educational material, and enhancing their information in the subject matter; consequently, this will expand the borders of their cognitive outcome, deepen the understanding of the public educational curricula and teach students autonomy and selfdependence (Clark \& Zimmerma, 1978).

Melvin(1999) suggested that the modern thinking process is based on the assumption that we can teach innovation and creativity, and that we can promote the individual performance of students by providing the suitable environment inside the house and school. Indeed, this urged some specialists to develop thinking skills programs aiming at enabling students to adapt to life's demands based on technological advancement and information revolution. Levin and Ornstein (1993) claimed that thinking skills are implicit abilities unless they are motivated and manifested by providing specialized programs teaching the creative thinking methods at schools. Torrance (1987) suggested that the future is a science by itself, and that it has certain characteristics that distinguish it from the other sciences, including its dependence on the mind that is paired with fiction, emotion and intuition; in addition, realizing the importance of time happens when we recognize the origin of problems in the past in addition to the upcoming future events. Human beings have the ability to influence the formation of the future manifested by several images (Treffinger \& Jackson, 2015).

\subsection{Creative Thinking}

The interest in teaching creativity to the talented is dated back to the second half of the $20^{\text {th }}$ century; the results of studies in the field of creativity focused on educational topics, teaching strategies, administrative practices and school environment in order to promote innovation and creativity among the talented students. Therefore, researchers proposed some methods for promoting creativity inside the school environment. Efforts were also made in order to discuss the factors that form an obstacle in front of the creative behavior inside the classroom (Fleith, 2000).

Bernardo and Zhang (2002) tackled the issue of addressing creativity. Some justifications are related to the rapid changes that societies face in all the domains which, in turn, require better use of the creative capabilities of the human beings to tackle and solve problems. Paying attention to creativity also satisfies important needs of the creative individuals (e.g., self-autonomy, exploration, curiosity, and experimentation). It also provides students with internal motivation that surpasses qualitatively and effectively all the external motivations. Furthermore, it contributes to improving their psychological health because practicing the creative activity satisfies the inherent needs and preferences among them. Torranc and Myers (2003) also advocated that using creative thinking skills contributes in solving problems and achieving the creative productivity; consequently, individuals who have no previous training on tackling problems can deal with them by using new methods in the light of unexpected emergent challenges. This, in turn, improves the type of genuine solutions of the future life problems.

Tomlinson (1995) suggested that every human being has a certain degree of intelligence and talent in a specific field of knowledge in which may be enhanced via training and teaching. Therefore, educationalists take into consideration the importance of providing students with attractive environment full of sensory stimulations; this provides them with psychologically attractive atmosphere instead of the psychologically negative circumstances that may hinder their healthy growth and development in the different aspects, namely emotional, spiritual, cognitive, skilled, linguistic, social, and physical aspects.

Flack (1996) suggested that students can be encouraged to be creative by exposing them to educational situations and employing enrichment activities to challenge their abilities and to allow them to express their opinions in a safe atmosphere. Al-Soroor (2015) argued that creative outcomes among the talented and creative individuals depend on some factors including intelligence, knowledge, thinking patterns, personality, motivation, and the content of the surrounding environment.

Promoting creative thinking has become a main objective in all the aspects of life, including the educational ones; enriching it with activities stimulating student's creativity to achieve the targeted objectives (Leonard, 2006). It also helps talented students acquire the strategies related to creative solution of the problems, make decisions, acquire the accurate thinking skills, and find the truth and the appropriate way for a solid perception about the future. Therefore, it is different from other programs offered to the talented students as it provides wider horizons for thinking and imagination which makes the student consider issues, problems and future solutions for them. All of them should be associated with managerial and technological horizons and other issues which are related to reality (Al-Soroor, 2015: 11).

A study was conducted by Azevedo et al., (2017) to apply the Future Problem-Solving Program model (FPSP) and to analyze its impact on developing the creativity skills. The results showed that there were statistically significant differences in the post-test between the two groups of participants in the study in favor of the experimental group which applied the FPSP.

Noreen's and his colleagues study (2014) aimed at investigating the role of thinking about the future in solving social problems. The study addressed the way of thinking about the consequences of a solved social problem or about unsolved problem due to changes in moods. The results showed that there was an evidence of the 
effectiveness of FPSP on problem solving. Treffinger et al., (2012) maintained that developing creative problem solving program and teaching ways of creative thinking among the secondary school students promotes their levels of talent and develop more vital images of their future, and increase their creative abilities. Hung (2003) revealed that the scores of the post-test for the scientific creativity and problem solving were much higher than the scores of the pre-test; this shows effectiveness of creative problem solving model.

\subsection{Future Problem- Solving Program}

The Future Problem-Solving Program is an international enrichment program developed by Torrance (1975) for talented students at different age groups and it helps them find a solution for a future problem through following some steps; which in turn simulates thinking about different issues in future life and offers distinctive solutions using creative thinking (Al-Soroor, 2015: 11). To put simply, the program aims at developing the skills of problemsolving, the skills of collective work, the awareness of future problems as well as taking the responsibility of solving these problems (Torrance \& Torrance, 1981). The program also predicts the changes and challenges that will take place in the future, the methods of dealing with them by offering logical solution and creative decisions, and taking the appropriate measures to adapt with the future changes and to survive (Starko, 2010). The program aims at addressing the future issues and providing positive solutions for problems, which in turn leads to forming positive attitudes among researchers based on reality.

Several studies confirmed the importance of the talented students' training on the program. Rewards and motivation increase the chance of taking advantage of their maximum abilities in order to offer the best solutions that contribute to developing their mental abilities as well as their creative thinking which will, in turn, support them with a variety of educational skills that enable them to solve the problems and consequently succeed in life (Treffinger et al., 2011).

Cramond (2009) also addressed the efforts made by many foreign countries, including the United States, South Africa, Australia, Korea, Hong Kong, England, Japan, Malaysia, New Zealand, Singapore, Thailand, Turkey in order to apply (FPSP) program, which is considered as one of the most important programs to enrich and train talented individuals, as well as enhancing the skills of creative thinking.

Torrance (1987) suggested that (FPSPI) program offers unique skills that correspond with the needs, characteristics and capabilities of the gifted students, improve their teamwork skills, and provide them with a variety of skills that help them expand their thoughts, consider the future horizons, and improve their talents.

Treffinger and Isaksen (2005) suggested that FPSP program helps the gifted students in solving the problems via the activities that it offers to them at all the levels. It also stimulates the students' critical and creative thinking skills and urges them to develop a vision for the future, since the program meets the standards related to curriculum, teaching methods, language, social studies, science, arts, mathematics, geography, education, technology, life skills as well as behavioral studies. It also provides the students with the opportunities through which they can develop and practice the necessary skills via research as well as investigating related topics. Furthermore, the program gives the students the opportunity to create a motivation for learning, and that helps teachers and trainers to, easily, apply the Future Problem- Solving Program in their schools.

According to the trainer manual (FPSP, 2015), the program is considered as one of the most prominent educational experiences that help the gifted students to think positively of the future. Additionally, its topics represent future imaginational image that may come true; therefore, it encourages students to activate their fiction and explore the different challenges in various domains for a limited period of time which, in turn, leads to finding out the appropriate solutions for such challenges. Indeed, it proved efficiency during a period of three decades. (Torrance, 1992) states that he often tells his students that Future Problem- Solving Program is one of the most important challenging educational experiences; however, it is one of the most interesting and beneficial. Therefore, each educationalist, according to his/her position, role and potentials should do his/her efforts to prepare a creative generation that is capable of achieving the promising future. The skill of conversation also has a vital role in communication and establishing relationships between groups in order to get to the best solutions; conversations and dialogues are changes and events that take place due to the existence of contradictory opinions as well as the individuality of emotions and perspectives (Patterson, 1987).

Smith (2016) did his efforts in order to discover new methods of teaching in the United States of America in an attempt to achieve effective teaching methods and suitable assessment methods that satisfy the developed needs that emerged during the previous years, including (FPSPI) which employs the creative steps for solving problems in order to offer solutions for the current universal problems.

Lewinshon et al., (2015) proved the effectiveness of learning based on (FPSPI) in order to improve the concept of environmental science and its benefit with regard to the environmental issues as well as for a variety of professionals in addressing the different problems through the effective participation in multi-discipline work groups that deal with the environmental issues by considering a solution for the future problems. Applying (FPSPI) program leads to developing the creative performance (Delcourt et al., 2015).

Syagili (2014) suggested that using (FPSPI) by the teachers who deal with the gifted students contributes to 
the emotional and social development of these students and that the skills of problem-solving among the children don't depend only on developing their academic talent even if they have high mental ability. Ayoub and Aljughaiman (2012) addressed (FPSPI) and the results revealed that there are statistically significant differences between the means of the individuals of the control and experiment groups regarding the creative abilities in favor of the experiment group.

Yarbrough and Tallent (1992) showed that there are statistically significant differences in the concerns and perceptions of the students participating in the program about the future in comparison with those who didn't participate in it and that there are differences in the interests of the students participating in the program, where they participate positively in the global issues in comparison with other students.

\section{The Study Problem and Questions}

The study problem emerged from the need to develop creative thinking skills among gifted students by implementing enrichment programs aiming at overseeing the future and solving problems creatively. The current programs offered to students do not satisfy their needs to become more aware of the future as well as the global changes which should enhance their thinking skills. The programs do not also apply activities like those included in FPSP. The FPSP activities aim to produce unique ideas and solutions, to prepare and enhance positive consideration of the future, and to develop the creative writing and dialogue using the creative solution of problems. Moreover, they promote the skills of creative thinking, and demonstrate the importance of activating the enrichment program (FPSP) to develop creative thinking among the gifted students. Hence, the current study aims at investigating the effectiveness of the enrichment program (FPSP) by improving the abilities and skills of gifted students to solve problems and think creatively. In addition, it examines the program continuity on the long run. Accordingly, the study questions were cited as follows:

1. Are there any statistically significant differences at the level of $(\alpha \leq 0.05)$ between the mean scores of the control and experimental group in the post-application on the scale of creative thinking skills attributed to the enrichment program?

2. Are there any statistically significant differences at the level of $(\alpha \leq 0.05)$ between the mean scores of the control and experimental group in the pre and post-application on the scale of creative thinking skills attributed to the enrichment program?

3. Are there statistically any significant differences at the level of $(\alpha \leq 0.05)$ between the mean scores of the control and experimental group in the post-application and follow-up on the scale of creative thinking skills attributed to the enrichment program?

The study importance lies in attracting the attention of those responsible for teaching the gifted students regarding the importance of teaching the creative thinking skills, either as future programs or by integrating them with their curricula, especially in the classrooms of the gifted. Thus, teachers can foster an atmosphere full of increased challenges, and prepare their students to the future. The study importance also lies in the modernity of this domain which gives more attention to gifted in the Arab region in comparison with the developed countries.

The limitation of the current study is restricted to the secondary stage schools, particularly in the gifted students classrooms in the Directorate of Al-Baha in KSA. The study is also limited to the second level of (FPSP) due to its compatibility to the age of the gifted students.

\section{Method of the Study}

3.1 The Study Population and Sample

The study population consisted of 76 gifted students in the $1^{\text {st }}$ secondary grade in Al-Baha. Their average age was (16) years old. The study sample was chosen purposefully from Al-Sarwat secondary school, since it includes the highest number of gifted students. The students who were gathered in the $1^{\text {st }}$ secondary grade got approval to be in one classroom (as part of the program for gifted) from the general directorate of Education in Al-Baha. The study sample of 24 students was divided into the experimental group (14) students, and the control group (10) students. The age of the sample ranged between (15-16) years old.

Based on the data of pre-performance on creative thinking scale, there were no statistically significant differences at the level of $(\alpha \leq 0.05)$ between the two groups. The researcher used the Mann-Whitney test for the independent samples as illustrated in table 1. This indicated that the results of the two groups were equal on the scale of creative thinking. 
Table 1. Mann-Whitney Test results of students' scores on the creative thinking pre-test

\begin{tabular}{|c|c|c|c|c|c|c|}
\hline Dimensions & Group & $\mathrm{N}$ & Average grade & Total grade & Mann-Whitney Test Value & Sig. \\
\hline Fluency & $\begin{array}{l}\text { Control } \\
\text { Experimental }\end{array}$ & $\begin{array}{l}10 \\
14\end{array}$ & $\begin{array}{l}13.50 \\
11.79\end{array}$ & $\begin{array}{l}135.00 \\
165.00\end{array}$ & 60.000 & 0.557 \\
\hline Flexibility & $\begin{array}{l}\text { Control } \\
\text { Experimental }\end{array}$ & $\begin{array}{l}10 \\
14\end{array}$ & $\begin{array}{l}9.50 \\
14.64\end{array}$ & $\begin{array}{l}95.00 \\
205.00\end{array}$ & 40.000 & 0.076 \\
\hline Details & $\begin{array}{l}\text { Control } \\
\text { Experimental }\end{array}$ & $\begin{array}{l}10 \\
14\end{array}$ & $\begin{array}{l}9.15 \\
14.89\end{array}$ & $\begin{array}{l}91.50 \\
208.50\end{array}$ & 36.500 & 0.860 \\
\hline Originality & $\begin{array}{l}\text { Control } \\
\text { Experimental }\end{array}$ & $\begin{array}{l}10 \\
14\end{array}$ & $\begin{array}{l}13.00 \\
12.14\end{array}$ & $\begin{array}{l}130.00 \\
170.00\end{array}$ & 65.000 & 0.768 \\
\hline Fantasy & $\begin{array}{l}\text { Control } \\
\text { Experimental }\end{array}$ & $\begin{array}{l}10 \\
14\end{array}$ & $\begin{array}{l}13.40 \\
11.86\end{array}$ & $\begin{array}{l}134.00 \\
166.00\end{array}$ & 61.000 & 0.598 \\
\hline Creativity & $\begin{array}{l}\text { Control } \\
\text { Experimental }\end{array}$ & $\begin{array}{l}10 \\
14\end{array}$ & $\begin{array}{l}11.85 \\
12.96\end{array}$ & $\begin{array}{l}118.50 \\
181.50\end{array}$ & 63.500 & 0.703 \\
\hline
\end{tabular}

\subsection{The Study Instrument}

The study consisted of two instruments: the program that the researchers derived from future dialogues with gifted students (the second level), and the scale of creative thinking skills developed by the researchers. The skills of creative thinking measured in the scale were based on FPSP (translated by Al-Soroor, 2015) in addition to the creative thinking skills taken from the second level of the enrichment program. The total number of items was (54 items).

3.2.1 The Enrichment Program

The researchers applied some of the skills that were chosen from the second level of (FPSPI). The educational curriculum for the gifted students was translated by Al-Soroor (2015). The activities included some dialogues that are suitable for the gifted students of the $1^{\text {st }}$ secondary grade in the classroom within the educational directorate of Al-Baha. The school administration allowed 22 meetings to the researcher. (FPSPI) consists of (52) educational units that have graded difficulty of three levels, and each unit has its own content that stimulates the gifted students to think of creative solutions for the issues included in all the dialogues (Al-Soroor, 2015).

The second level of the future dialogues was adopted in order to solve the problems during the application of the program and included: the awareness of details' description, dealing with crises, conscience, the traits of personality, future leaderships, expressing future imagination, preserving the Earth to improve the quality of life, common links, science fiction, and the poems. The second level was chosen because it was compatible with the age and level of the study sample. The reason for selecting these specified items from the second level was also attributed to the lack of time taking into consideration the restricted number meetings (22) with students. Each meeting consisted of two classes of the creativity lessons allocated for them in the program. Therefore, the researchers selected the skills that were more compatible for their local environment and that highly stimulate the students.

\subsection{The Validity Scale}

In order to establish the construct validity of the scale, it was administered to a pilot sample consisted of 40 students from the different schools which have classroom for gifted students. The researchers calculated the coefficient correlation between the study dimensions as illustrated in table 2. The table shows that the coefficient correlation between the dimensions was high and there were statistically significant at the level $(\alpha \leq 0.05)$.

Table 2. The coefficient correlation between the dimensions of the creative thinking

\begin{tabular}{|l|l|l|l|l|l|}
\hline Dimensions & Fluency & Flexibility & Details & Originality & Fantasy \\
\hline Fluency & - & & & & \\
\hline Flexibility & $.773^{* *}$ & - & & & \\
\hline Details & $.803^{* *}$ & $.778^{* *}$ & - & & \\
\hline Originality & $.815^{* *}$ & $.712^{* *}$ & $.809^{* *}$ & - & \\
\hline Fantasy & $.838^{* *}$ & $.787^{* *}$ & $.812^{* *}$ & $.811^{* *}$ & \\
\hline Creativity & $.929^{* *}$ & $.861^{* *}$ & $.904^{* *}$ & $.908^{* *}$ & $.952^{* *}$ \\
\hline$(\alpha \leq 0.05)^{* * *}(\alpha \leq 0.01)$
\end{tabular}

Based on the calculations, the construct validity of the scale was found to be acceptable. It also matches the aims of the study measuring creative thinking skills among the gifted students.

In order verify the scale reliability, the reliability coefficient was calculated by using test- re-test within two weeks from the test applied to pilot sample. The reliability ranged between $(0.80-0.91)$, which is considered as suitable values for the current study. 


\section{Results and Discussion}

In order to answer the first question "are there statistically significant differences at the level of $(\alpha \leq 0.05)$ between the mean scores of the control and experimental groups in the post-application creative thinking skills scales attributed to the enrichment program?", the means and standard deviations were calculated for the two groups. The results showed that there were apparent differences between the means of the students' performance on the post-test of creative thinking in general as well as on its different dimensions. Mann-Whitney test was performed for the independent samples to find any statistical differences as illustrated in Table 3.

Table 3. Mann-Whitney Test results of students' scores on the creative thinking post-test

\begin{tabular}{|c|c|c|c|c|c|c|}
\hline Dimensions & Group & Number & $\begin{array}{l}\text { Average } \\
\text { grade }\end{array}$ & $\begin{array}{l}\text { Total } \\
\text { grade }\end{array}$ & $\begin{array}{l}\text { Mann-Whitney } \\
\text { Test Value }\end{array}$ & $\begin{array}{l}\text { Statistical } \\
\text { significance }\end{array}$ \\
\hline Fluency & $\begin{array}{l}\text { Control } \\
\text { experimental }\end{array}$ & $\begin{array}{l}10 \\
14\end{array}$ & $\begin{array}{l}5.50 \\
17.50\end{array}$ & $\begin{array}{l}55.00 \\
245.00\end{array}$ & 0.000 & 0.000 \\
\hline Flexibility & $\begin{array}{l}\text { Control } \\
\text { Experimental }\end{array}$ & $\begin{array}{l}10 \\
14\end{array}$ & $\begin{array}{l}5.50 \\
17.50\end{array}$ & $\begin{array}{l}55.00 \\
245.00\end{array}$ & 0.000 & 0.000 \\
\hline Details & $\begin{array}{l}\text { Control } \\
\text { experimental }\end{array}$ & $\begin{array}{l}10 \\
14\end{array}$ & $\begin{array}{l}5.50 \\
17.50\end{array}$ & $\begin{array}{l}55.00 \\
245.00\end{array}$ & 0.000 & 0.000 \\
\hline Originality & $\begin{array}{l}\text { Control } \\
\text { experimental }\end{array}$ & $\begin{array}{l}10 \\
14\end{array}$ & $\begin{array}{l}5.50 \\
17.50\end{array}$ & $\begin{array}{l}55.00 \\
245.00\end{array}$ & 0.000 & 0.000 \\
\hline Fantasy & $\begin{array}{l}\text { Control } \\
\text { experimental }\end{array}$ & $\begin{array}{l}10 \\
14\end{array}$ & $\begin{array}{l}5.50 \\
17.50\end{array}$ & $\begin{array}{l}55.00 \\
245.00\end{array}$ & 0.000 & 0.000 \\
\hline Creativity & $\begin{array}{l}\text { Control } \\
\text { experimental }\end{array}$ & $\begin{array}{l}10 \\
14\end{array}$ & $\begin{array}{l}5.50 \\
17.50 \\
\end{array}$ & $\begin{array}{l}55.00 \\
245.00\end{array}$ & 0.000 & 0.000 \\
\hline
\end{tabular}

Table 3 showed that the value of Mann-Whitney test on the scale of creative thinking was significant $(0.000$ at the level of $(\alpha \leq 0.05)$; this means that the program had significant impact on the experimental group in comparison with the control group. In other words, the program was effective and had a favorable benefit in developing the skills of creative thinking among the students of the gifted classrooms in comparison with the other provided programs.

The researchers attributed this result to the effectiveness of the procedures used by the program as well as the clarity of the objectives that were implemented. The idea of discussing the future and its developments were also considered to stimulate students to think creatively taking into consideration the ambiguity associated with the future. Furthermore, it promotes the expectations of the targeted students towards the future as opposed to the school enrichment program which is formally introduced in the gifted classrooms. The school program normally addresses solving the creative problem without considering the ideas of the future presented by the program of the current study. The findings of this study was in agreements with the results of (Lewinsohn, 2015; Delcourt et al., 2015; Azevedo et al., 2017; Saygili, 2014; Whyte \& Dritsche 2014; Noreen, Trifinger \& Woythal, 2012; Hung, 2003 Tallant, 1985; Dufner, 1984; and Yarprough \& tallant, 1992) with regard to developing creative thinking among students. Even though not all of them used the program of future dialogues, they were similar with the current study in using programs for developing creative thinking and gave an evidence of development among the study sample. However, the researchers did not find studies about the programs that were applied to develop the creative thinking and showed contradictory results for this one. The results revealed that the proposed program had a positive impact on developing the skills of creative thinking among the experimental group individuals. The experimental group individuals showed a distinctive performance in offering unfamiliar ideas about the future via (FPSP) program. By answering activities, it was evident that the individuals of the experimental group had a good imagination about the future as well as their high ability to express through the program activities. Hence, there was a considerable impact of enrichment program on developing creative thinking.

In order to answer the second question if there any statistically significant differences at the level of $(\alpha \leq 0.05)$ in creative thinking skills attributed to the enrichment program the for the experimental group in the pre and postapplication of the scale of, Wilcoxon Signed Ranks Test (as illustrated in table 4) was used to find out these differences. The means and standard deviations were also calculated for pre and post-applications for the experimental group. The results showed that there were apparent significant differences between the means of the targeted students' estimation degree on the scale of creative thinking in total as well as on its different dimensions. The number of positive ranks was (9) and there were no negative ranks. The total of ranks was (406) which was statistically significant at the level of (0.000). The means of ranks for the post-application were higher than the pre-application and the differences were in favor of the students' performance in the post-application in total and its different dimensions, indicating the effectiveness of the enrichment program. 
Table 4. Wilcoxon Signed Ranks Test results of the experimental students' scores on the creative thinking pre- and post-test

\begin{tabular}{|c|c|c|c|c|c|c|}
\hline Dimensions & Negative ranks & Number & Average grade & Total grade & $Z$ & Sig. \\
\hline \multirow{4}{*}{ Fluency } & Negative ranks & $28^{\mathrm{a}}$ & 14.50 & 406.00 & \multirow{4}{*}{$-4.627^{b}$} & \multirow{4}{*}{.000} \\
\hline & Positive ranks & $0^{\mathrm{b}}$ & 0.00 & 0.00 & & \\
\hline & Equal ranks & $0^{\mathrm{c}}$ & & & & \\
\hline & Total & 28 & & & & \\
\hline \multirow{4}{*}{ Flexibility } & Negative ranks & $28^{\mathrm{a}}$ & 14.50 & 406.00 & \multirow{4}{*}{$-4.627^{b}$} & \multirow{4}{*}{.000} \\
\hline & Positive ranks & $0^{\mathrm{b}}$ & 0.00 & 0.00 & & \\
\hline & Equal ranks & $0^{\mathrm{c}}$ & & & & \\
\hline & Total & 28 & & & & \\
\hline \multirow{4}{*}{ Details } & Negative ranks & $28^{\mathrm{a}}$ & 14.50 & 406.00 & \multirow{4}{*}{$-4.625^{b}$} & \multirow{4}{*}{.000} \\
\hline & Positive ranks & $0^{\mathrm{b}}$ & 0.00 & 0.00 & & \\
\hline & Equal ranks & $0^{\mathrm{c}}$ & & & & \\
\hline & Total & 28 & & & & \\
\hline \multirow{4}{*}{ Originality } & Negative ranks & $28^{\mathrm{a}}$ & 14.50 & 406.00 & \multirow{4}{*}{$-4.624^{b}$} & \multirow{4}{*}{.000} \\
\hline & Positive ranks & $0^{\mathrm{b}}$ & 0.00 & 0.00 & & \\
\hline & Equal ranks & $0^{\mathrm{c}}$ & & & & \\
\hline & Total & 28 & & & & \\
\hline \multirow{4}{*}{ Fantasy } & Negative ranks & $28^{\mathrm{a}}$ & 14.50 & 406.00 & \multirow{4}{*}{$-4.624^{b}$} & \multirow{4}{*}{.000} \\
\hline & Positive ranks & $0^{\mathrm{b}}$ & 0.00 & 0.00 & & \\
\hline & Equal ranks & $0^{\mathrm{c}}$ & & & & \\
\hline & Total & 28 & & & & \\
\hline \multirow{4}{*}{ Creativity } & Negative ranks & $28^{\mathrm{a}}$ & 14.5 & 0 & \multirow{4}{*}{406} & \multirow{4}{*}{.000} \\
\hline & Positive ranks & $0^{\mathrm{b}}$ & 0 & 45 & & \\
\hline & Equal ranks & $0^{\mathrm{c}}$ & & & & \\
\hline & Total & 28 & & & & \\
\hline
\end{tabular}

The researchers attributed this result to the effectiveness of the program, to the procedures used in the study, to the effectiveness of (FPSP) in teaching the gifted students in public schools, and to the possibility of its implementation by teachers in the gifted classrooms. These results were confirmed by other studies on the effectiveness of the program mentioned in Al-Soroor (2015). These results may also support the main idea on which programs of teaching creativity are based. It is argued that creative thinking with its dimensions represent traits that can be developed among gifted students via programmed experiences and educational processes at schools.

The results of this study agreed with the results of (Lewinsohn, 2015; Delcourt et al., 2015; Azevedo et al., 2017; Saygili, 2014; Trifinger \& Woythal, 2012; Tallant,1985; Pakmaster, 1994; and Yarprough \& Tallant, 1992), which reveal that the proposed program had a positive impact on developing the skills of future dialogues for solving problems related to creative thinking among the experimental groups as opposed to control groups; FPSP program include activities that help the gifted students to acquire communication skills and to solve the problems creatively. In addition, the program develops the ability to discuss and argue by mastering the skill of fluent speaking, and it develops using imagination in solving future problems; moreover, it addresses the ability to narrate events during the conversational activities and writing the desired scenarios about the future to promote authenticity. Performing the dialogues that require linguistic fluency helped the students demonstrate skills related to details in a positive and creative way as manifested in their writings via the activities of the enrichment program.

To answer the third question of this current study "are there any statistically significant differences between the two groups at the level of $(\alpha \leq 0.05)$ in creative thinking skills attributed to the enrichment program in the postapplication and follow-up of the scale", Wilcoxon Signed Ranks Test was performed to find out any significance differences between the two groups (see Table 5 below). The means and standard deviations were also calculated for the post-application and follow-up for the experimental group. The results showed that there were obvious significant differences between the means of the targeted students' performance on the scale of creative thinking during the post-measurement and follow-up in total. In order to confirm the significance of these statistical differences, 
Table 5. Wilcoxon Test for differences in the experimental group scores in the pre-and post- applications and scores of creative thinking

\begin{tabular}{|c|c|c|c|c|c|c|}
\hline Dimensions & Negative ranks & Number & Average ranks & Total ranks & $Z$ & Sig \\
\hline \multirow{4}{*}{ Fluency } & Negative ranks & $28^{\mathrm{a}}$ & 14.50 & 406.00 & \multirow{4}{*}{$-4.629^{b}$} & \multirow{4}{*}{.000} \\
\hline & Positive ranks & $0^{\mathrm{b}}$ & 0.00 & 0.00 & & \\
\hline & Equal ranks & $0^{\mathrm{c}}$ & & & & \\
\hline & Total & 28 & & & & \\
\hline \multirow{4}{*}{ Flexibility } & Negative ranks & $28^{\mathrm{a}}$ & 14.50 & 406.00 & \multirow{4}{*}{$-4.631^{b}$} & \multirow{4}{*}{.000} \\
\hline & Positive ranks & $0^{\mathrm{b}}$ & 0.00 & 0.00 & & \\
\hline & Equal ranks & $0^{\mathrm{c}}$ & & & & \\
\hline & Total & 28 & & & & \\
\hline \multirow{4}{*}{ Details } & Negative ranks & $28^{\mathrm{a}}$ & 14.50 & 406.00 & \multirow{4}{*}{$-4.627^{b}$} & \multirow{4}{*}{.000} \\
\hline & Positive ranks & $0^{\mathrm{b}}$ & 0.00 & 0.00 & & \\
\hline & Equal ranks & $0^{\mathrm{c}}$ & & & & \\
\hline & Total & 28 & & & & \\
\hline \multirow{4}{*}{ Originality } & Negative ranks & $28^{\mathrm{a}}$ & 14.50 & 406.00 & \multirow{4}{*}{$-4.627^{b}$} & \multirow{4}{*}{.000} \\
\hline & Positive ranks & $0^{\mathrm{b}}$ & 0.00 & 0.00 & & \\
\hline & Equal ranks & $0^{\mathrm{c}}$ & & & & \\
\hline & Total & 28 & & & & \\
\hline \multirow{4}{*}{ Fantasy } & Negative ranks & $28^{\mathrm{a}}$ & 14.50 & 406.00 & \multirow{4}{*}{$-4.626^{\mathrm{b}}$} & \multirow{4}{*}{.000} \\
\hline & Positive ranks & $0^{\mathrm{b}}$ & 0.00 & 0.00 & & \\
\hline & Equal ranks & $0^{\mathrm{c}}$ & & & & \\
\hline & Total & 28 & & & & \\
\hline \multirow{4}{*}{ Creativity } & Negative ranks & $28^{\mathrm{a}}$ & 14.5 & 0 & \multirow{4}{*}{$-4.627^{b}$} & \multirow{4}{*}{.000} \\
\hline & Positive ranks & $0^{\mathrm{b}}$ & 0 & 45 & & \\
\hline & Equal ranks & $0^{\mathrm{c}}$ & & & & \\
\hline & Total & 28 & & & & \\
\hline
\end{tabular}

Table 5 shows that the number of positive ranks is (9) and that there are no equal or negative ranks; the total of ranks was (406) which is statistically significant at the level of $(0.000)$; where the difference between the means of ranks and their total in the results of Wilcoxon test regarding the post-performance and follow-up of the students on the total score of the scale and its different dimensions was statistically significant at $(\alpha \leq 0.05)$ and attributed to the variable of application (post, follow-up). Since the means of ranks for the follow-up are higher than the postapplication, the differences are in favor of the students' performance in the follow-up, indicating the continuous effectiveness of the enrichment program, as well as confirming the results of the first and second hypotheses.

The researchers attributed this result to the students' familiarity with the scale of creative thinking skills which was applied for the third time as well as the continuous self-training of the program, where the gifted students in the experimental sample asked the researcher to give them the program exercises in order to practice them by themselves in their free time. The researcher provided each student with a copy of the program and also provided the teachers with copies of the program, indicating the interaction of the school teachers and students with the program.

The results of this study was in agreement with the results of (Noreen et al., 2014; Dufner, 1984; Tallant, 1985; Yarprough \& Tallant, 1992). The results revealed that gifted student of the $1^{\text {st }}$ secondary stage, during the follow-up, had a curiosity to learn the creative thinking skills related to (FPSP). They also had an obvious interest in identifying the extent of correlation between the skills that they practice with creative thinking and future dialogues related to problem-solving. This indicates that the gifted students acquired those skills, which showed statistically significant improvement. The impact was clear and positive in the follow-up test results. It was also evident that the gifted students possessed the creative thinking skills related to the enrichment program. This suggests the positive impact of the enrichment program on their creative thinking skills.

Based on the previous findings, we notice that the program is effective in the enrichment of gifted students. It is considered a good way for developing their abilities to predict the future and solve its problems in addition to developing creative thinking skills among them. The activities included in the program are appropriate and important for the direct development of these skills independently from the basic curriculum of the public schools taking into consideration the need for linking the program activities with reality. The FPSP program provides gifted students with competitive opportunities to meet the real life needs and challenges within a range of proposed topics regarding different issues related to them.

\section{Recommendation and Conclusion}

The results of the this research contribute to achieving self-learning, to developing patterns of thinking, to 
promoting motivation and positive attitudes towards learning, to increasing effectiveness and coping with the technological and scientific development, and to creating more fun atmosphere in learning and achieving of continuous learning. The findings based on the students' performance on the activities of the enrichment program showed a significant role for the activities in providing students with the skills that enhance their visions about the future as well as their thinking and problem-solving skills. Consequently, students will have more knowledge about future and will realize their role and participation in shaping their future. Their confidence will increase their abilities and potentials and will enhance their attitudes positively towards the future and motivate them to be more creative.

\section{References}

Aljughaiman, A., \& Ayoub, A. (2012). The effect of an enrichment program on developing analytical, creative, and practical abilities of elementary gifted students. Journal for the education of the gifted, 35(2). https://doi.org/10.1177/0162353212440616

Azevedo, I., Morais, M. de F., \& Martins, F. (2017). The Future Problem-Solving Program International: An Intervention to Promote Creative Skills in Portuguese Adolescents. The Journal of Creative Behavior, version of recorded online 11 May. https://doi.org/10.1002/jocb.175

Cramond, B. (2009). Future Problem Solving in gifted education. In L. Shavinna (Ed.). Handbook on Giftedness (Part 2, pp. 1143- 1156). NY: Springer. https://doi.org/10.1007/978-1-4020-6162-2 58

Delcourt, Marcia A. B., Main, Laura F. \& Treffinger, Donald J. (2015). Effects of VIEW style training on Future Problem-Solving Performance. Presentation at the VIEW/SOQ Conference, Buffalo, NY.

Fleith, D. (2000). Teacher and student perceptions of Creativity in the class room environment. Roepert Review, 3(22), 148-154. https://doi.org/10.1080/02783190009554022

Hume, K. (2001). The future problem-solving program. Parenting for High Potential, 8-11.

Hung, W. (2003). A Study of Creative Problem Solving Instructional Design and Assessment in Elementary School Chemistry Courses. Chinese Journal of Science Education, 11(4), P.P. 407-430.

Lewinsohn, C. R. F., Gislene, G., Leonardo, R. J., Johannes, K., Gerhard, E. O. D. P., Daniela, P., \& Wolfgang, W. W. (2015). The effectiveness of applying the future problem solving program to solve a wide range of future environmental problems among students who are illiterate. The Royal Swedish Academy of Sciences. AMBIO 2015, 44, 154-162. https://doi.org/10.1007/s13280-014-0539-2

Noreen, S., \& Whyte, K. E., \& Dritschel, B. (2014). Investigating the role of future thinking in social problem solving. University of St Andrews. Journal of Behavior Therapy and Experimental Psychiatry. https://doi.org/10.1016/j.jbtep.2014.08.004

Patterson, L (1987). Plateaus careers productivity. Development quantity (53) 5.

Saygili, G. (2014). Problem-solving skills employed by gifted children and their peers in public primary schools in Turkey. Social behavior and personality journal, 42. https://doi.org/10.2224/sbp.2014.42.0.S53

Smith, M. C. (2016). Utilizing the FPSPI Framework for Creative Problem Solving Across the Curriculum: AN Exploration of Methods Utilized by Successful Teachers (PhD Dissertation, Capella University).

Starko, A. J. (2010). Creativity in the Classroom - Schools of Curious Delight. NewYork: Routledge. https://doi.org/10.4324/9780203871492

Al-Srour, N. H., Ali, S. M., \& Oweidi, A. A (2016 ). The impact of teacher training on creative writing and problem-solving using Futuristic scenarios for creative problem solving and creative problem solving programs. Education, 136(4), 461-476.

Tallent, M. K. (1985). The Future Problem-Solving Program: An Investigation of Effects on Problem Solving Ability. ERIC ED297485: https://archive.org/details/ERIC ED297485

Tallent-Runnels, M. K., \& Yarbrough, D. W. (1992). Effects of The Future Problem-Solving Program on children's concerns about the future. Gifted child quarterly, 36. https://doi.org/10.1177/001698629203600404

Tallent-Runnels, M. K. (1993). The Future Problem-Solving Program: An investigation of effects on problemsolving ability. Contemporary Educational Psychology, 18, 382-388. https://doi.org/10.1006/ceps.1993.1028

Tarawneh, A. A. (2015). Reflective Thinking and its Relationship with Future Problem Solving for Mutah University. British Journal of Humanities and Social Sciences, 13(2), 25-31.

Torrance, E. P. (1987). Guiding Creative Talent. Englewood Cliffs, NJ: Prentice-Hall Inc.

Treffinger, D. J., \& Isaksen, S. G. (2005). Creative problem solving: History, development, and implications for gifted education and talent development. Gifted Child Quarterly, 49, 342-353. https://doi.org/10.1177/001698620504900407

Treffinger, D. J., Isaksen, S. G., \& Stead-Dorval, K. B. (2006). Creative problem Solving: An Introduction (4th ed.). Waco, TX: Prufrock.

Treffinger, D. J., Schoonover, P. F., \& Selby, E. C. (2013). Education for Creativity and Innovation. Waco, TX: Prufrock. 
Treffinger, D. J., Solomon, M., \& Woythal, D. (2012). Four decades of creative vision: Insights from an evaluation of the Future Problem-Solving Program International (FPSPI). The Journal of Creative Behavior, 46. https://doi.org/10.1002/jocb.14

Treffinger, D. J, \& Jackson, J. (2009). FPSPI: Past, Present, and Future. Melbourne: FL. Future Problem Solving Program International.

Treffinger, D. J. (2000). Practice Problems for Creative Problem Solving (3rd ed.) Waco,TX: Prufock Press. 